\title{
Fisheries Biology of the Roundnose Flounder, Eopsetta grigorjewi HerzensteIn, in the South-western Japan Sea and Its Adjacent Waters-VI. Early Stage in Development and Growth by Rearing
}

\author{
Yojiro IMAOKA*1 and Hiroshi Misu*2
}

(Received July 27, 1974)

\begin{abstract}
Imaoka has reported on the results of long-term rearing of the roundnose flounder, Eopsetta grigorjewi HERzENSTEIN, in an aquarium. In this paper, the authors report on its spawning, hatching, and larval rearing in an aquarium.

The experiments were conducted from February to March of 1972 and 1973. The eggs obtained by natural spawning and artifical fertilization began to hatch out at about $102 \mathrm{hrs}$ (when the water temperature was regulated between $12-13^{\circ} \mathrm{C}$ during daytime and $8-10^{\circ} \mathrm{C}$ in the night) and $75 \mathrm{hrs}$ (when the room temperature was regulated at $14^{\circ} \mathrm{C}$ ).

The rate of artificial fertilization was $85-93 \%$. The rotifer as the first food was given after three days of hatch-out.

In those experiments, death of larvae decreased after the tenth day and the averaeg body length of larvae was $6.7-7.0 \mathrm{~mm}$ by the twenty fifth day of rearing.
\end{abstract}

IMAOKA $^{1)}$ has reported on the results of long-term rearing of the roundnose flounder, Eopsetta grigorjewi HERZENSTEIN, in an aquarium. In this paper, the authors report on its spawning, hatching and larval rearing in an aquarium. The development of the egg and rearing of flat fish larva have been studied by YUSA ${ }^{21}$ and FuJrt ${ }^{31}$. They used eggs fertilized artificially on a fishing boat but only small number of larvae was examined. In this paper the development of the egg and rearing of laravl fish obtained by natural and artificial spawning are reported. The development of eggs and the external morphology of the larval fish are described only briefly, as the details have been reported by YUSA $^{2)}$ and FUлтA ${ }^{3)}$. Because the larval fish obtained by natural spawning were all $\operatorname{dead}^{* 3}$ one week after hatching, only those from artificial fertilization are mainly reported.

\section{Materials and Methods}

The experiments were conducted in 1972 and 1973. The adult fishes used in the first experiment were collected by the beam trawl of the fisheries reasech vessel, Asakaze (19.99 ton) in the waters north of Hamada on January 31, 1972. They were

*1 Shimane Prefectural Fisheries Experimental Station（今岡要二郎：島根県水産試鈳場）

*2 Seikai Regional Fisheries Research Laboratory（西海区水産研究所：三栖宽）

*3 A strong atmorpheric cold wave had swept the western Japan during February 26 and March 4, 1973. At that time all the larval fish died because of the low water temperature which could not be regulated. 
reared for ten days in an aquarium $(183 \times 167 \times 58 \mathrm{~cm})$ and food was given. From which two females $(28.0 \mathrm{~cm}, 26.7 \mathrm{~cm}$ in body length) and four males (average body length $22.4 \mathrm{~cm}$ ), were selected for intermuscular injection of "Shinahorin". They were placed in an aertated tank $(150 \times 60 \times 45 \mathrm{~cm})$ and kept in a dark room. The water temperature was regulated between $12-13^{\circ} \mathrm{C}$ during daytime and $8-10^{\circ} \mathrm{C}$ in the night.

The adult fishes used in the second experiment were collected by another beam trawl of the fisheries research vessel, Akikaze (39.43 ton) in north western waters off Hamada on January 31 and February 1, 1973. They were held for fourteen days in an aquarium $(183 \times 167 \times 58 \mathrm{~cm})$ and live food was given from the third day. Then, "Shinahorin" was injected in four females (average body length $27.8 \mathrm{~cm}$ ) and six males (average body length $23.3 \mathrm{~cm}$ ). They were kept in two water circulated tanks (150X $60 \times 45 \mathrm{~cm}$ and $150 \times 55 \times 40 \mathrm{~cm}$ ) and placed in a room, where the room temperature was regulated at $14^{\circ} \mathrm{C}$.

\section{Observation}

Natural spawning This species showed a negative phototaxis and crept into the bottom sand when illuminated, though it adaptated itself to the light later. Accordingly, the observation of the fish was some what difficult. As the "Shinahorin" injected females showed no change during the first five days, injection was practised again on the sixth day after the beginning of the experiment. The males were not injected again, because the sperm could be extracted easily by applying slight pressure against the abdomen. Though the abdomen of the female slightly became swollen on the seventh day, the spawning did not appear to begin. On the eighth day, females seemed to be induced spawning by lying of male upon them. However, the authors could not observe the act for long, as they hid themselves in the sand, when illuminated. Many eggs were found just under the surface of the water and in a filter tank on the evening of the eighth day at 5:30 p.m. The eggs were collected by net immediately and were placed in two glass tanks $(30 \times 28 \times 15 \mathrm{~cm})$.

Artificial fertilization. The abdomen of females became swollen a little $22 \mathrm{hr}$ after the "Shinahorin" injection, but eggs were not released out. The ripe eggs were discharged

Table 1. Data of artificial fertilization and rate of fertilization

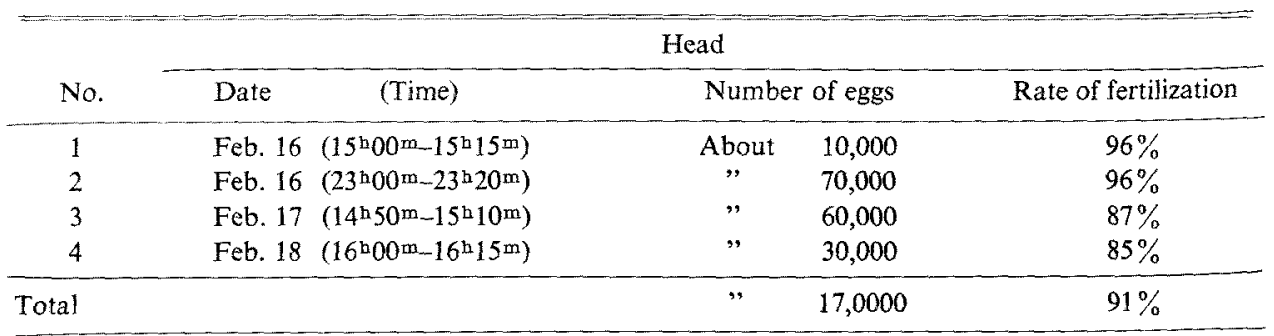


out from one female $(28.7 \mathrm{~cm}$ in body length; this specimen is referred as " $\mathrm{A}$ " after this) at $67 \mathrm{hrs}$ after the injection. These eggs were immediately fertilized artificially (by using physiological salt solution and by the ordinary humidity method). About 10,000 eggs were obtained at the beginning, and ripe eggs were successively obtained from individual " $A$ ".

When its abdomen became swollen, it spawned easily by any slight shock. The results are shown in Table 1 . The eggs were obtained four times, for this experiment, although more eggs could be obtained from individual " $\mathrm{A}$ ".

\section{Egg development}

Natural spawning The eggs were 1.1 to $1.3 \mathrm{~mm}$ in diameter and without oil-globule (Fig. 1). The two-cell stage was reached at $3 \mathrm{hrs}$ after fertilization (Fig. 2), eight-cell stage at $4.5 \mathrm{hrs}$ (Fig. 3), 16-cell stage at $6 \mathrm{hrs,} \mathrm{32-cell} \mathrm{stage} \mathrm{at} 7.5 \mathrm{hrs}$, the blastula stage at $13 \mathrm{hrs}$ and the gastrula stage at $17 \mathrm{hrs}$ (Fig. 4) after fertilization, respectively. The embryo began to differentiate at $50 \mathrm{hrs}$ after fertilization (Fig. 5). Differentiation of the optic vesicle and appearance of black pigments on the embryo took place at $59 \mathrm{hrs}$ after fertilization. The embryonic movement was observed at $93 \mathrm{hrs}$ after fertilization (Fig. 6). The larvae hatched out at $102 \mathrm{hrs}$ after fertilization (Fig. 7). This result agrees with that of YUSA ${ }^{2}$, who reported that the embryo hatched at $100 \mathrm{hrs}$ after fertilization. The number of spawning eggs were estimated to be about 47,000 but many of them were overriping.

The rate of fertilization was very low, about $8.1 \%$ only but the rate of hatching was high and was estimated to be $70 \%$.

Artificial fertilization The first cleavage was observed at $2.5 \mathrm{hrs}$ after fertilization. The 16-cell stage was attained at about $5 \mathrm{hrs,} 32$-cell stage at $6 \mathrm{hrs}$, and the morula stage at about $7.5 \mathrm{hrs}$. Theblastula stage was reached at about $11 \mathrm{hrs}$ and the gastula stage at about $15 \mathrm{hrs}$ after fertilization. At abotut $30 \mathrm{hrs}$ after fertilization, the mbryonic differentiation stage was attained and the optic vesicle stage was attained at about $35 \mathrm{hrs}$. Embryonic movement was observed at $70 \mathrm{hrs}$. The larvae began to hatch out at about 75 hrs after fertilization.

Table 2. Number of larvae and rate of hatching

\begin{tabular}{|c|c|c|c|c|c|c|}
\hline \multirow{3}{*}{$\frac{\text { No. }}{1}$} & \multicolumn{6}{|c|}{ Head } \\
\hline & \multicolumn{2}{|c|}{ Number of eggs } & \multicolumn{2}{|c|}{ Number of larvae } & \multicolumn{2}{|c|}{ Rate of hatching } \\
\hline & About & 9,600 & About & 8,900 & About & $93 \%$ \\
\hline 2 & $"$ & 67,200 & 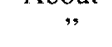 & 58,000 & " & $86 \%$ \\
\hline 3 & $"$ & 52,200 & , & 46,000 & $"$ & $88 \%$ \\
\hline 4 & $"$ & 24,600 & , & 20,000 & $"$ & $82 \%$ \\
\hline Total & $"$ & 154,000 & $"$ & 132,900 & $"$ & $87.3 \%$ \\
\hline
\end{tabular}




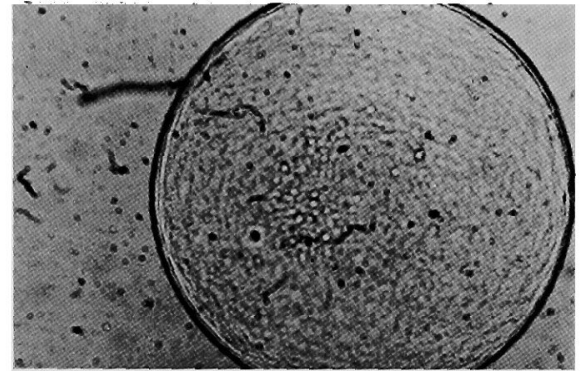

Fig. 1. Newly fertilized egg ( 1 hrs after fetrilization).

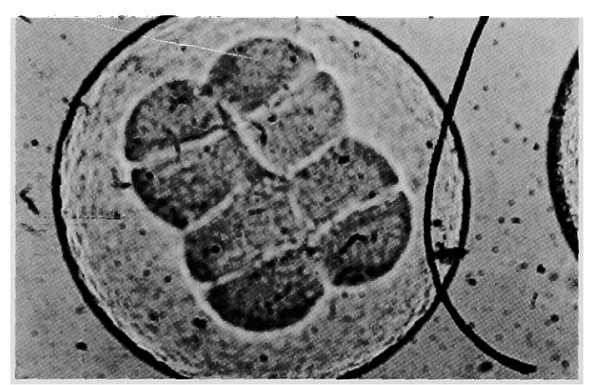

Fig. 3. Eight cell stage $(4.5 \mathrm{hrs}$ after fertilization).

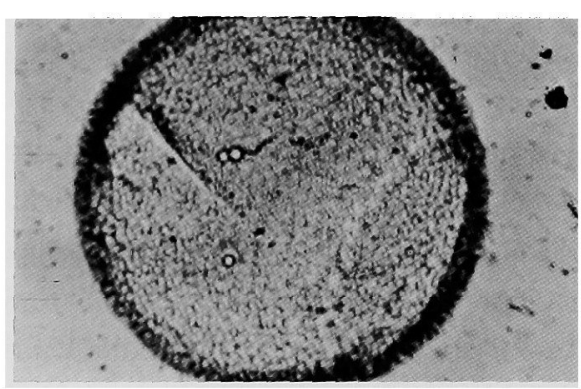

Fig. 5. Embryonic differentiation stage (50 hrs after fertilization).

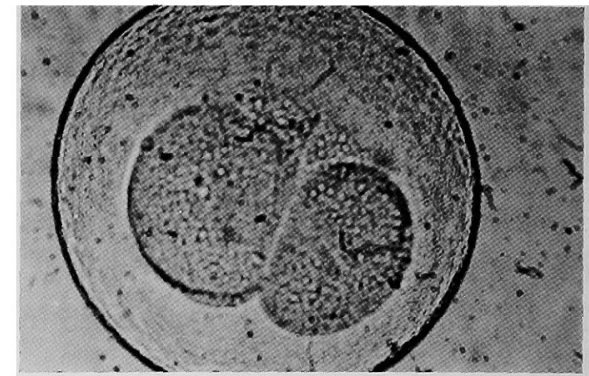

Fig. 2. Two cell state ( $3 \mathrm{hrs}$ after fertilization).

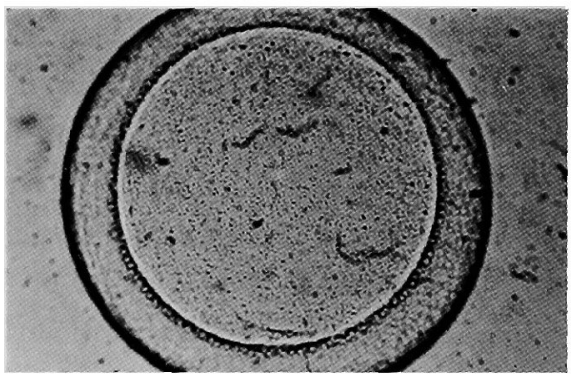

Fig. 4. Gastrula stage $(17 \mathrm{hrs}$ after fertilization).

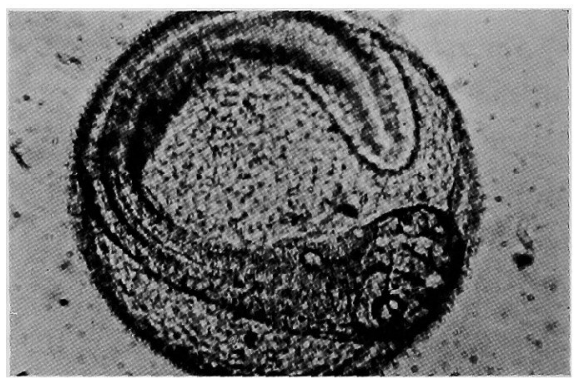

Fig. 6. Embryonic movement stage (93 hrs after fertilizatino).

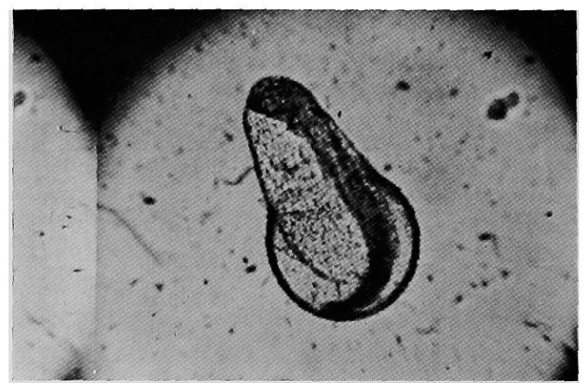

Fig. 7. Hatching (102 hrs after fertilization). 
This result genrally agrees with that of FUJITA ${ }^{3)}$, who reportd the hatching began at $74 \mathrm{hr}$ after fertilization.

The number of eggs used in this experiment was estimated to be 170,000 . The hatching rate is shown in Table 2 .

\section{Rearing of the larval fish}

Natural fertilization Two small aquaria tanks $(30 \times 20 \times 15 \mathrm{~cm})$ and three beakers (1 liter) were used. The sea water in one tank was circulated and the others were keeped in natural condition. Two houndred fishes were held in each tank. Fifty fish were kept in each beaker. As many dead larvae were found in th water circulated tank, the circulation was stopped and the water was only aerated. The death seemed to be caused by small splinters of the glass-fiber used for filtration. The larval fish kept in the other containers grew favorably. Boiled yolk of hen's egg filtered through the gauze was given on the third day after hatching, but the fish were not observed to take it. The water temperature had dropped to $0^{\circ} \mathrm{C}$ or so by abnormal cold weather on the sixth day and all of the larval fish were killed by the low temperature.

Artificial fertilization. Four acryl water tanks (400, 200, 100 and 80 liter) were used and the water was slightly aerated. The newly hatched larvae were placed in these containers and $1 / 5$ to $1 / 3$ of the water in each tank was changed every two days during the first week and every day after that (the water was changed everyday). Light was controlled at the level of 20-40 lux at the surface of the water and these tanks were illuminated from sunrise to sunset.

The newly hatched larva were $2.9-3.2 \mathrm{~mm}$ in total length and the horizontal diameter of the yolk sac was 1.3-1.4 mm (Fig. 8).

The larva is slender, delicate and transparent, excet the head part where is covered with membranous fin. The larva is $3.5-3.8 \mathrm{~mm}$ in total length two days after hatching, and grow to $4.2-4.3 \mathrm{~mm}$ in total length on the third day. By this time the eyeball had projected and the anus opened compeltely. The mouth also opened on the

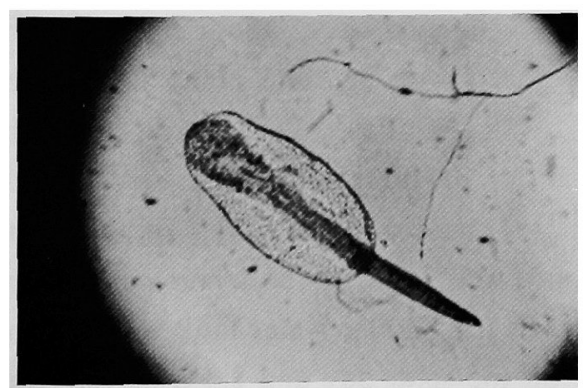

Fig. 8. Newly hatched larva (first day).

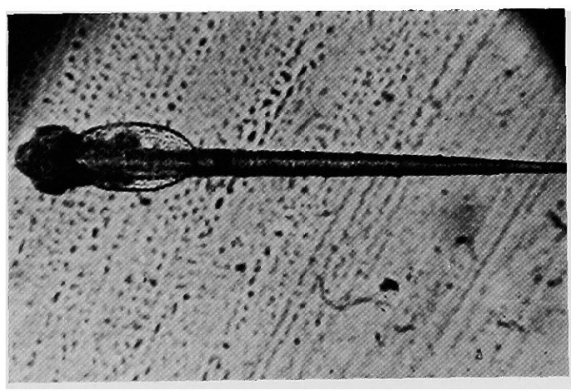

Fig. 9. Fifth day larva. 
third day and the pectoral fin differentited. This phenomenon seems to be related with the ability of swimming, especially of ngesting food debris. At the end of the third day, rotifers was given as food as a density of 1 rotifer per cc. of sea water. On the fourth day (113 hrs after hatching) the digestive organs were found filled with rotifers. The larva attained $4.5-4.7 \mathrm{~mm}$ in total length on the fifth day after hatching (Fig. 9). On the seventh day, the larva absorbed its yolk completely and attained $4.8-5.3 \mathrm{~mm}$ in total length. On the tenth day, the digestive organ was fully developed and had differentiated into three parts. The swimming ability of the larval fish became very active and they stayed in the lower layer of water. The larva attained 5.5-5.9 $\mathrm{mm}$ in total length on the fifteenth day after hatching, and the action of taking food could be observed with the naked eye.

The larva attained $6.2-6.5 \mathrm{~mm}$ in total length on the twentieth day after hatching and the body width increased. The larva attained $6.7-7.0 \mathrm{~mm}$ in total length on the twentyfifth day after hatching. By the end of the twenty-fifth day all the larvae had died.

Death during early stage The number of dead larvae was counted every two days for 18 days succeeding hatching and the results are shown in Fig. 10.

The number of the larval fish

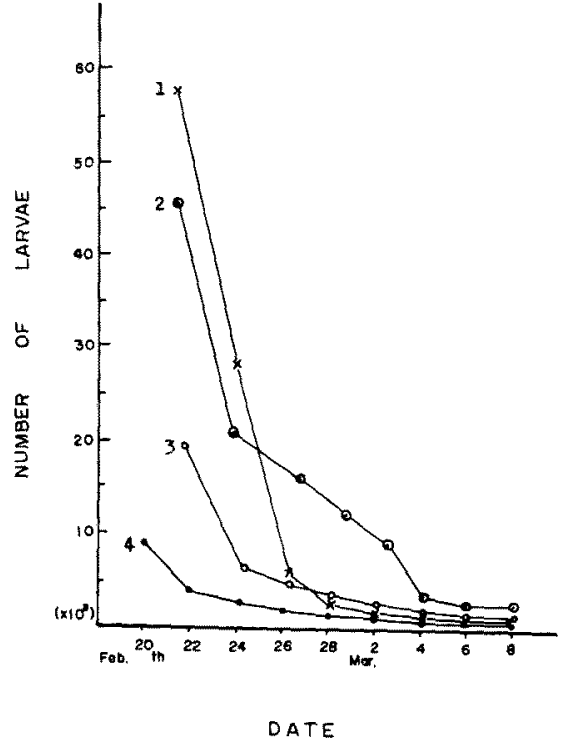

Fig. 10. Death of larvae during early development stage (1-4, a number of water thank). reared was $22,290,460$ and 250 per liter in 400, 200, 100 and 80 liter water tank respectively. The survival rate was about $60 \%$ during the fourth day and about $25 \%$ on the sixth day in the 400 liter water tank. Though the number of death slightly decreased thereafter, the survival rate was about $8 \%$ on the twelfth day after hatching. The rate of survival in the 200 liter water tank was about $52 \%$ on the second day, about $11 \%$ on the fourth day and about $3 \%$ on the tenth day. The survival rate in the 100 liter water tank was $44 \%$ on the second day, $34 \%$ on the fourth day, $26 \%$ on the sixth day, $10 \%$ on the eigh day, and $1.5 \%$ of the larvae survived on the tenth day after hatching. The survival rate in the 80 liter water tank was $35 \%$ on the second day, $20 \%$ on the fourth day, $17 \%$ on the sixth day and $2.5 \%$ on the tenth day after hatching. In general death of larvae decreased after the tenth day. About 
1,500 larval fish, which had begun feeding were transported from Hamada to Kashima by a car. The rate of death was about $14 \%$ by three hours after of transporatation.

Consideration The development of eggs and the metamorphosis described in this paper are generally similar to those of YUSA $^{21}$ and FuJita ${ }^{3)}$. As shown in Table 3, the growth of the larval fish in this experiment is faster than those reported by YUSA ${ }^{2}$, but generally agrees with that of FUJITA ${ }^{31}$. As both reports are based on the observation from the first seven days after hatching, the growth after that can not be compared. YUSA $^{2)}$ mentioned that larval fish immediately after hatching had large quantity of yolk, which added to the buoyancy of the larva, and that they floated and swam upside down near the surface of the water. According to the authors' observation, the newly hatched larvae floated almost motionlessly for one or two days. Sometimes they swam obliquely, but they hardly swam normally.

Because of the development of the membranous fin in the vertical plane of the body, the authors consider that the larvae does not appear to float upside down easily. Furthermore, FujITA ${ }^{3 \prime}$ reported that the larva swam freely in the first two days after hatching and that the larvae began to peak at the bottom of the tank on the third day after hatching with their head pointing downward, to which he referred as a feeding activity.

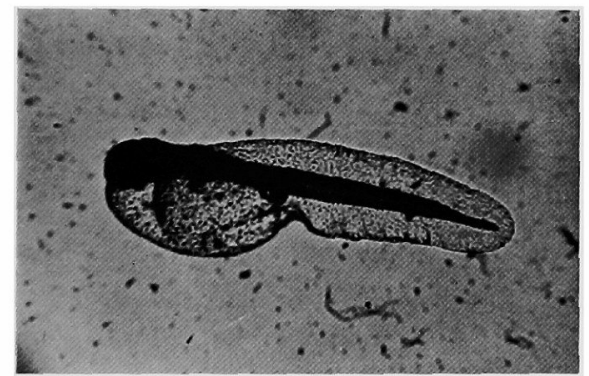

Fig. 11. Membranous fin develops in the vertical plane of the larva (after hatching).

Table 3. Comparison of the total lengths of larvae obtained in this study with the former results reported by the several authors

\begin{tabular}{|c|c|c|c|c|c|c|c|c|c|c|}
\hline \multirow{2}{*}{$\begin{array}{l}\text { Name of } \\
\text { observer }\end{array}$} & \multicolumn{10}{|c|}{ Number of days } \\
\hline & 1 & 2 & 3 & 4 & 5 & 7 & 10 & 15 & 20 & 25 \\
\hline YUSA & $\begin{array}{l}2.8 \mathrm{~mm} \\
3.0\end{array}$ & - & - & - & $\begin{array}{l}42 \\
4.3\end{array}$ & 44 & & & & \\
\hline FujITA & $\left.\right|_{3.2} ^{3.0 \mathrm{~mm}}$ & 3.7 & 4.25 & 4.4 & 4.5 & - & & & & \\
\hline IMAOKA & $\begin{array}{l}2.9 \mathrm{~mm} \\
3.2\end{array}$ & 3.5 & 4.2 & - & $i_{4.6}^{4.5}$ & $i_{4.8}^{4.6}$ & $i_{5.3}^{4.8}$ & 5.5 & $\begin{array}{l}6.2 \\
6.5\end{array}$ & $\begin{array}{l}6.7 \\
7.0\end{array}$ \\
\hline
\end{tabular}


The mouth opened in full three days as noted above and larva swam only inactively on the third day after hatching. The authors consider that the larva swim with their head pointed obliquely downward is because of its heavy yolk sac located in the anterior half of the body. Almost all larvae kept an attitude inclined anteriorly even in the state of repose. It was often observed that the larvae thrust to feed by moving their caudal portion and stopped suddenly by pectoral fin action.

As for the death during early stage, KURATA ${ }^{4}$ reported that the critical point on the development of the larvae would not appear during the stage of beginning to feed after the absorption of yolk, but appear during the later staage. In this experiment, however, relatively large number of death occured on about tenth day after hatching, or a week after beginning of feeding. The metamorphosis of this fish did not begin till twenty fifth day of rearing.

\section{Acknowledgements}

The authors would like to express their sincere thanks to Prof. Tokimi Tsujira, Faculty of Fisheries, Hokkaido University, Dr. Osamu KIBESAKI, Director of Seikai Regional Fisheries Research Laboratory, Dr. Tsuneo Aoyama, Chief of Oceanoagraphy Division of Seikai Regional Fisheries Research Laboratory and Mr. Tsutoshi AraI, Director of Shimane Prefectural Fisheries Experimental Station for the manuscript revision.

\section{References}

1) Y. IMAOKA: This Bull, 40, 39-45 (1974).

2) T. YUSA: Bull. Tohoku Reg. Fish. Lab., 19, 109-117 (1961).

3) S. Fujrta: This Bull., 31, 258-262 (1965).

4) H. Kurata: Bull. Tohoku Reg. Fish. Lab., 5, $20-28$ (1954). 